\title{
ANALISIS PENDAPATAN USAHATANI BAWANG DAUN DI DESA SINSINGON KECAMATAN PASSI TIMUR KABUPATEN BOLAANG MONGONDOW
}

\author{
Leslyanti Agatha Welang \\ Gene Henfried Meyer Kapantow \\ Benny Adrian Berthy Sagay
}

\begin{tabular}{ll}
\hline Naskah diterima melalui Website Jurnal Ilmiah agrisosioekonomi@ unsrat.ac.id & : Jumat, 10 Januari 2020 \\
Disetujui diterbitkan & : Senin, 13 Januari 2020 \\
\hline
\end{tabular}

\begin{abstract}
This study aims to analyze the income of leek farming. This research was conducted in Sinsingon Village, Passi Timur District, Bolaang Mongondow Regency. This research lasted for 3 months from November 2018 to January 2019. Sampling in this study was carried out by simple random sampling, as many as 30 farmers. Primary data collection used in this study using survey methods by means of direct interviews with the help of questionnaires. Secondary data were obtained by the Sinsingon Village office. Analysis of the data used in this research is descriptive analysis and is presented in tabular form. To see the level of economic benefits of scallions will be used analysis of revenue, costs, income, then proceed with the analysis of the return cost ratio. The results showed that the the average revenue of leek farming per farmer is $R p$. 24,400,020 per planting season and the total average cost per farmer is $R p .11,229,083$, resulting in an average income per farmer of $R p$. 13,170,937 per growing sesion. The $R / C$ was 2.17 which that the onion farming in Sinsingon Village, Passi Timur District was profitable. ${ }^{*}{ }^{2}$ rm*
\end{abstract}

Keywords: revenue analysis, leek

\begin{abstract}
ABSTRAK
Penelitian ini bertujuan untuk menganalisis pendapatan usahatani bawang daun. Penelitian ini dilakukan di Desa Sinsingon, Kecamatan Passi Timur, Kabupaten Bolaang Mongondow. Penelitian ini berlangsung selama 3 bulan sejak bulan November 2018 sampai Januari 2019. Pengambilan sampel dalam penelitian ini dilakukan secara acak sederhana (simple random sampling), sebanyak 30 petani yang berusahatani bawang daun. Pengumpulan data primer yang digunakan dalam penelitian ini dengan menggunakan metode survey dengan cara wawancara langsung dengan bantuan kuesioner. Data sekunder diperoleh kantor Desa Sinsingon. Analisis data yang digunakan dalam penelitian ini adalah analisis deskriptif dan disajikan dalam bentuk tabel. Untuk melihat tingkat keuntungan ekonomis bawang daun akan digunakan analisis penerimaan, biaya, pendapatan, kemudian dilanjutkan dengan analisis return cost ratio. Hasil penelitian menunjukkan bahwa penerimaan usahatani bawang daun rata-rata per petani adalah Rp.24.400.020 per musim tanam dan total biaya rata-rata per petani adalah Rp.11.229.083 sehingga menghasilkan pendapatan rata-rata per petani sebesar Rp.13.170.937 per musim tanam. rasio R/C sebesar 2,17 artinya usahatani bawang daun di Desa Sinsingon Kecamatan Passi Timur mengalami keuntungan sehingga usaha ini layak diusahakan. ${ }^{*}$ eprm*
\end{abstract}

Kata kunci : analisis pendapatan, bawang daun

Agrisosioekonomi: 


\section{PENDAHULUAN}

Indonesia merupakan negara yang sedang melaksanakan pembangunan di segala bidang, termasuk sektor pertanian merupakan salah satu sektor yang diandalkan untuk menunjang laju pertumbuhan ekonomi nasional, karena sektor pertanian terbukti mampu menunjang pemulihan ekonomi bangsa dan diharapkan mampu memberikan pemecahan permasalahan sebagian besar penduduk Indonesia. Kegiatan pokok dan sumber pendapatan utama masyarakat, khususnya masyarakat di pedesaan, masih tergantung pada sektor pertanian. Hal ini dapat diartikan bahwa kehidupan dari sebagian besar rumah tangga tergantung pada sektor ini (Nurmanaf, 2003).

Pertanian adalah motor penggerak bagi sektor-sektor lain sehingga dapat menunjang tujuan pembangunan pertanian, taraf hidup petani, memperluas lapangan kerja, kesempatan usaha dalam mendorong pembangunan perekonomian, pertumbuhan dinamika ekonomi pedesaan yang pada gilirannya akan memberikan peluang mensejahterakan kehidupan masyarakat secara lebih banyak khususnya di daerah pedesaan (Rahardi dkk, 2004)

Pada saat terjadi krisis ekonomi di Indonesia, komoditas hortikultura yang meliputi tanaman sayuran, buah-buahan, dan tanaman hias merupakan salah satu pemicu pertumbuhan ekonomi baru pada sektor pertanian. Sayuran tergolong kedalam salah satu jenis tanaman hortikultura yang kaya akan vitamin dan mineral sehingga banyak dikonsumsi oleh masyarakat, namun tingkat konsumsi sayuran juga dipengaruhi oleh berbagai faktor, misalnya harga dan tingkat pendapatan. Banyaknya manfaat sayuran bagi pemenuhan gizi masyarakat menyebabkan sayuran menjadi bagian dari komoditas hortikultura yang terus diproduksi. Bahkan beberapa produk komoditas sayuran Indonesia telah menjadi mata dagang ekspor dan sumber devisa negara. Oleh karena itu, produksi, produktivitas, dan kualitas sayuran nasional perlu ditingkatkan terutama untuk jenis sayuran potensial yang selama ini belum mendapat perhatian. Salah satu jenis komoditas sayuran potensial dan layak dikembangkan secara intensif dalam skala agribisnis adalah bawang daun (Allium fistulosum L.). Tanaman ini diduga berasal dari kawasan Asia Tenggara, kemudian meluas ditanam di berbagai daerah (Negara) yang beriklim tropis maupun subtropis (Meltin, 2009).
Bawang daun adalah salah satu jenis tanaman sayuran yang berpotensi dikembangkan secara intensif dan komersil. Selain itu luas areal panen bawang daun di Indonesia setiap tahun terus meningkat, karena prospek pemasaran komoditas ini menunjukkan kecenderungan yang semakin baik. Pemasaran produksi bawang daun segar tidak hanya untuk pasar dalam negeri (domestik) melainkan juga pasar luar negeri (ekspor). Selain itu, permintaan bawang daun akan semakin meningkat seiring dengan meningkatnya laju pertumbuhan penduduk (Cahyono, 2005)

Kondisi lahan dan cuaca di Indonesia yang sangat sesuai untuk pengembangan bawang daun. Selain itu, pembudidayaan bawang daun relatif mudah dan murah. Perkembangan produksi bawang daun dari tahun ke tahun cenderung meningkat. Meskipun pernah terjadi penurunan luas panen pada tahun 2003 dan 2005, namun penurunan luas panen tersebut tidak diikuti oleh penurunan produksi maupun produktivitas bawang daun. Hal ini terlihat dari nilai produksi dan produktivitas bawang daun pada tahun 2003 dan 2005 yang justru meningkat dari tahun sebelumnya. Hal ini disebabkan adanya perbaikan teknologi atau teknik penanaman dalam usahatani bawang daun (Dewi, 2015).

Usaha peningkatan produksi dan pendapatan tergantung pada perilaku petani yang berusahatani. Berhasil tidaknya suatu usahatani dalam mencapai tujuan tergantung dari cara pengolahan cabang usahatani yang dikelolanya dimana petani berperan sebagai manager yang berkewajiban untuk mengambil keputusan mengenai pilihan dan harus mampu menentukan pola usahatani yang hendak diselenggarakan serta bagaimana cara mengolah usahatani tersebut.

Dalam pengelolaan suatu usahatani, petani mengupayakan agar hal yang diperoleh secara ekonomis menguntungkan, dimana biaya yang dikeluarkan dapat menghasilkan produksi yang maksimal. Sehingga pada akhirnya pendapatan petani meningkat, dan dengan meningkatnya pendapatan maka secara otomatis tingkat kesejahteraan petani tersebut akan meningkat.

Produksi pertanian sangat tergantung pada alam sebagai sumber daya utamanya, sehingga pendapatan yang diperoleh tidak stabil, begitu pula dalam produksi usahatani bawang daun. Dalam pengembangan usaha tingkat produksi dan pendapatan yang diperoleh petani sangat dipengaruhi oleh beberapa hal diantaranya lahan, cuaca, modal dan pengetahuan tentang usaha tani tersebut. 
Lahan yang luas dapat berpengaruh dalam banyaknya bawang daun yang akan di tanam, lahan yang luas akan meningkatkan hasil produksi bawang daun dan lebih menambah pendapatan petani serta kesejahteraan masyarakat yang menjalankan usaha tani. Kemudian adanya campur tangan alam dalam usahatani ini merupakan efek yang sangat penting, jika musim hujan tiba maka warga dapat memberikan air yang berkecukupan, sehingga warga tidak hanya berharap pada air yang mereka olah sendiri ke lahan mereka.Kemudian modal yang menjadi faktor utama dalam menjalankan usaha tani ini sangat memiliki pengaruh yang besar, tanpa modal maka tak akan ada pembelian bibit, pupuk maupun semua alat yang dibutuhkan dalam usahatani tersebut. Yang terakhir yaitu pengetahuan, ilmu pertanian berpengaruh agar warga tidak sembarangan dalam menanam bawang daun, dan dapat mengatasi hama yang merusak tanaman bawang daun. Luas panen, Produksi dan hasil per hektar tanaman bawang daun di Provinsi Sulawesi Utara tahun 2017 dapat dilihat pada Tabel 1.

Tabel 1. Luas Panen, Produksi dan Hasil per Hektar Tanaman Bawang Daun di Provinsi Sulawesi Utara tahun 2017

\begin{tabular}{|c|c|c|c|c|}
\hline No & Kabupaten/Kota & $\begin{array}{l}\text { Luas } \\
\text { Panen } \\
(\mathrm{Ha}) \\
\end{array}$ & $\begin{array}{l}\text { Produksi } \\
\text { (Kuintal) }\end{array}$ & $\begin{array}{c}\text { Hasil per } \\
\text { Hektar } \\
\text { (Kuintal/Hektar) }\end{array}$ \\
\hline 1 & Bolaang Mongondow & 9.901 & 64.107 & 6,47 \\
\hline 2 & Minahasa & 189 & 13.905 & 73,57 \\
\hline 3 & Talaud & 39 & 860 & 22,05 \\
\hline 4 & Minahasa Selatan & 1.848 & 230.200 & 124,57 \\
\hline 5 & Minahasa Tenggara & 107 & 1.438 & 13,44 \\
\hline 6 & $\begin{array}{l}\text { Bolaang Mongodow } \\
\text { Selatan }\end{array}$ & 4 & 12 & 3,00 \\
\hline 7 & $\begin{array}{l}\text { Bolaang } \\
\text { Mongondow Timur }\end{array}$ & 1.605 & 39.923 & 24,87 \\
\hline 8 & Bitung & 16 & 169 & 10,56 \\
\hline 9 & Tomohon & 289 & 23.249 & 80,45 \\
\hline 10 & Kotamobagu & 1 & 3 & 3,00 \\
\hline & Jumlah & 13.999 & 373.866 & 361,98 \\
\hline
\end{tabular}

Tabel 1 menunjukkan bahwa kabupaten/ kota di Provinsi Sulawesi Utara yang jumlah produksinya kedua terbanyak adalah Bolaang Mongondow, tingkat produksi tahun 2017 mencapai 64.107 Kuintal, ini berarti Kecamatan Passi Timur juga berpengaruh dalam peningkatan produksi bawang daun di Kabupaten Bolaang Mongondow.
Perkembangan dan produksi tanaman bawang daun dapat dilihat pada Tabel 2 .

Tabel 2 menunjukkan bahwa di Kecamatan Passi Timur yang jumlah produksinya terbanyak adalah Desa Sinsingon, produktifitas mencapai 20 ton dan produksi mencapai 1740 ton. ini berarti Desa Sinsingon juga berpengaruh dalam peningkatan produksi bawang daun di Kecamatan Passi Timur.

\begin{tabular}{clcc} 
Tabel & $\begin{array}{c}\text { 2. } \\
\text { Tanaman Bawang Daun di Kecamatan Passi Timur }\end{array}$ \\
\hline No & \multicolumn{1}{c}{ Desa } & $\begin{array}{c}\text { Perkembangan Produktifitas Dan } \\
\text { Produksi Bawang Daun (Ton) }\end{array}$ \\
\cline { 3 - 4 } & & - & Produksi \\
\hline 1 & Pangian Barat & - & - \\
2 & Pangian Tengah & - & - \\
3 & Pangian & - & - \\
4 & Poopo Barat & - & - \\
5 & Poopo Selatan & - & - \\
6 & Poopo & 7 & - \\
7 & Manembo & 20 & 350 \\
8 & Sinsingon Barat & 20 & 1011 \\
9 & Sinsingon & 20 & 1740 \\
10 & Sinsingon Timur & 13 & 1550 \\
11 & Insil & 18 & 600 \\
12 & Insil Baru & 13 & 810 \\
13 & Mobuya &
\end{tabular}

Tabel 2 menunjukkan bahwa data yang diperoleh dari kepala desa atau sangadi setempat bahwa $80 \%$ penduduk berprofesi sebagai petani bawang daun. Tanaman ini merupakan salah satu sumber pendapatan petani setiap tahunnya disamping pendapatan petani dari tanaman lainnya. Besarnya pendapatan ini dapat digunakan untuk menilai keberhasilan petani dalam mengelolanya. Keberhasilan dalam berusahatani bawang daun pada akhirnya akan ditentukan oleh biaya yang dikeluarkan dan penerimaan yang diperoleh dalam satu musim tanam. Manfaat utama dari pendapatan tersebut adalah untuk menjamin keberlanjutan usahataninya. Pendapatan memiliki arti penting bagi petani yaitu untuk meningkatkan taraf hidup petani. Petani bawang daun di Desa Sinsingon perlu memperhatikan banyak hal untuk memperoleh pendapatan yang besar agar usahatani bawang daun dapat efisien, serta kontribusi pendapatan yang diperoleh dapat lebih tinggi dibandingkan dari sumber pendapatan lainnya terhadap pendapatan total rumah tangga petani di Desa Sinsingon. 


\section{Perumusan Masalah}

Berdasarkan latar belakang yang dimaksud, maka menjadi masalah dalam penelitian ini adalah bagaimana pendapatan usahatani bawang daun di Desa Sinsingon, Kecamatan Passi Timur, Kabupaten Bolaang Mongondow?

\section{Tujuan Penelitian}

Penelitian ini bertujuan untuk menganalisis pendapatan usahatani bawang daun di Desa Sinsingon, Kecamatan Passi Timur, Kabupaten Bolaang Mongondow.

\section{Manfaat penelitian}

Manfaat penelitian ini adalah diharapkan menjadi bahan masukkan bagi pemerintah, pengusaha, petani dan peneliti. Juga sebagai bahan informasi bagi pihak yang berkepentingan dalam pengembangan suatu usahatani khususnya usahatani bawang daun.

\section{METODE PENELITIAN}

\section{Tempat dan Waktu Penelitian}

Penelitian ini berlangsung selama 3 bulan sejak bulan November 2018 sampai Januari 2019, mulai dari persiapan sampai penyusunan laporan hasil penelitian. Tempat penelitian di Desa Sinsingon, Kecamatan Passi Timur, Kabupaten Bolaang Mongondow.

\section{Metode Pengumpulan Data}

Pengumpulan data yang digunakan dalam penelitian ini dengan menggunakan metode survey yang meliputi data primer dan data sekunder. Data primer diperoleh di lapangan tempat penelitian dalam hal ini adalah masyarakat Desa Sinsingon yang merupakan petani bawang daun, dengan cara mewawancari langsung dengan menggunakan koisioner. Data sekunder diperoleh dari instansi dan kantor desa. Data yang diperlukan dalam penelitian ini yaitu data tentang jumlah penduduk, mata pencaharian dan lainnya.

\section{Metode Pengambilan Sampel}

Objek dalam penelitian ini adalah petani bawang daun di Desa Sinsingon. Pengambilan sampel dalam penelitian ini dilakukan secara acak sederhana (simple random sampling), sebanyak 30 petani yang berusahatani bawang daun.

\section{Konsepsi Pengukuran Variabel}

1. Karakteristik petani:

a. Umur petani (Tahun)

b. Tingkat pendidikan (SD, SMP, SMA, PT)

c. Jumlah anggota keluarga (orang)

d. Pengalaman berusahatani bawang daun (tahun)

2. Variabel utama dalam penelitian ini meliputi:

1) Luas lahan, yaitu luas lahan keseluruhan yang digunakan dalam usahatani bawang daun (Ha).

2) Biaya produksi yaitu biaya yang dikeluarkan petani dalam satu kali proses produksi, meliputi biaya tetap dan biaya tidak tetap.

a. Biaya tetap yaitu biaya yang tidak berhubungan langsung dengan barang yang diproduksi yaitu meliputi:

1) Pajak tanah, besarnya sesuai dengan luas dan daya guna lahan (Rp/thn)

2) Penyusutan alat, yaitu nilai penggunaan cangkul, sekop dan hand sprayer yang disebabkan oleh pemakaiannya selama proses produksi berlangsung (Rp). Perhitungan penyusutan alat menggunakan rumus:

$\mathrm{D}(\mathrm{Rp})=\frac{\text { Harga awal }(\mathrm{Rp})-\text { Harga akhir }(\mathrm{Rp})}{\text { Waktu pakai(Thn) }}$

b. Biaya tidak tetap (variabel) yaitu biaya yang langsung mempengaruhi besarnya produksi yang dihasilkan terdiri dari:

1) Bibit, yaitu pengeluaran biaya bibit yang digunakan oleh petani dalam usahataninya $(\mathrm{Rp})$.

2) Tenaga kerja, yaitu tenaga kerja yang digunakan dan jenis tenaga kerja serta sumber sumber tanaga kerja. Jumlah tenaga kerja diukur dalam upah tenaga kerja. (Rp)

3) Pupuk, yaitu banyaknya pupuk yang digunakan oleh petani dalam usahataninya $(\mathrm{Rp} / \mathrm{kg})$.

4) Pestisida, yaitu banyaknya pestisida yang digunakan oleh petani dalam usahataninya $(\mathrm{Rp} / \mathrm{kg})$.

3) Produksi, yaitu jumlah produksi bawang daun yang diperoleh dalam satu kali tanam (Larik). Satu larik berkisar antara $1 \mathrm{Kg}$ sampai $1,5 \mathrm{Kg}$, dimana dalam satu larik terdiri dari 4 atau 5 rumpun bawang daun dengan jarak antar larik yaitu $25 \mathrm{~cm}$, dan jarak antar tanaman yaitu $15 \mathrm{~cm}$. 
4) Harga, yaitu harga yang berlaku ditingkat petani (Rp/Larik).

5) Penerimaan adalah perkalian antara produksi dengan harga jual (Rp/Larik).

6) Pendapatan usahatani adalah selisih antara penerimaan dan biaya produksi (Rp).

\section{Metode Analisis data}

Analisis data yang digunakan dalam penelitian ini adalah analisis deskriptif dan disajikan dalam bentuk tabel. Untuk melihat tingkat keuntungan ekonomis bawang daun akan digunakan analisis penerimaan, biaya, pendapatan, kemudian dilanjutkan dengan analisis return cost ratio.

a) Penerimaan usahatani adalah perkalian antara produksi yang diperoleh dengan harga jual. Peryataan ini dapat di tulis sebagai berikut.

$$
\mathrm{TR}=\mathrm{Y} \text {. PY }
$$

Dimana:

TR $=$ Total Penerimaan

$\mathrm{Y}=$ Produksi yang diperoleh dalam usahatani

Py $=$ Harga yang berlaku

b) Biaya Total adalah jumlah uang yang dikeluarkan untuk memproduksi bawang daun dengan rumus:

Dimana:

$$
\mathrm{TC}=\mathrm{FC}+\mathrm{VC}
$$

$\mathrm{TC}=$ Total Cost (Total Pengeluaran)

$\mathrm{FC}=$ Fixed Cost (Biaya Tetap)

$\mathrm{VC}=$ Variabel Cost (Biaya Variabel)

c) Pendapatan adalah selisih antara penerimaan dan semua biaya dengan rumus:

$$
\mathrm{Pd} \quad=\mathrm{TR}-\mathrm{TC}
$$

Dimana:

$\mathrm{Pd}=$ Pendapatan Usahatani

$\mathrm{TR}=$ Total revenue $($ Total Penerimaan $)$

$\mathrm{TC}=$ Total cost $($ Total Pengeluaran $)$

d) Revenue cost ratio adalah perbandingan antara penerimaan dengan biaya-biaya yang dikeluarkan selama proses produksi hingga menghasilkan produk. Dengan rumus :

Dimana:

$$
a=R / C
$$

$$
\begin{aligned}
& \mathrm{a}=\text { Revenue cost ratio } \\
& \mathrm{R}=\text { Revenue } \\
& \mathrm{C}=\text { Cost }
\end{aligned}
$$

Secara teoritis dengan ratio $\mathrm{R} / \mathrm{C}$ :

$>1$ Usahatani tersebut mengalami keuntungan $=1$ Artinya usahatani tidak untung dan tidak rugi $<1$ Artinya usahatani mengalami kerugian

\section{HASIL DAN PEMBAHASAN}

\section{Deskripsi Lokasi Penelitian}

\section{Keadaan Geografis Lokasi Penelitian}

Desa Sinsingon merupakan salah satu desa yang terletak di Kecamatan Passi Timur, Kabupaten Bolaang Mongondow, Provinsi Sulawesi Utara. Luas wilayah Desa Sinsingon $21.700 \mathrm{Ha}$, jarak dengan ibukota kabupaten/kota $89 \mathrm{~km}$. Wilayah ini merupakan dataran tinggi \pm 1.100 - $1300 \mathrm{mdpl}$, jenis tanah adalah Andosol dan Letosol dengan topografi landai sampai berbukit, $\mathrm{pH}$ tanah netral. Suhu terendah berkisar $15^{\circ} \mathrm{C}$, tertinggi $32^{\circ} \mathrm{C}$ dan rata-rata $20^{\circ} \mathrm{C}$.

Penduduk Desa Sinsingon berjumlah 715 jiwa (347 laki-laki dan perempuan 368) termasuk dalam 233 kepala keluarga (Statistik Desa Sinsingon) serta sebagian besar penduduk bermata pencaharian sebagai petani. Batas wilayah administratif Desa Sinsingon sebagai berikut :

a. Sebelah Utara : Desa Sinsingon Timur

b. Sebelah Selatan: Desa Sinsingon Barat

c. Sebelah Barat: Hutan Lindung

d. Sebelah Timur : Perkebunan Sinsingon Timur

\section{Karakteristik Responden}

\section{Umur Petani}

Umur petani akan mempengaruhi kemampuan fisik dalam bekerja. Petani yang masih muda dan sehat akan berproduktivitas lebih besar dari pada petani yang sudah tua. Dari 30 petani responden bawang daun di Desa Sinsingon Kecamatan Passi Timur Kabupaten Bolaang Mongondow menunjukkan bahwa kisaran umur petani adalah $20-72$ tahun, seperti terlihat pada Tabel 3.

Tabel 3. Jumlah Petani Menurut Golongan Umur

\begin{tabular}{lcr}
\hline $\begin{array}{c}\text { Umur Petani } \\
\text { (Tahun) }\end{array}$ & $\begin{array}{c}\text { Jumlah Petani } \\
\text { (Orang) }\end{array}$ & Persentase (\%) \\
\hline $20-35$ & 4 & 13 \\
$36-50$ & 18 & 60 \\
$51-65$ & 7 & 24 \\
$>66$ & 1 & 3 \\
\hline Jumlah & 30 & 100 \\
\hline Sumber : Diolah dari data primer, 2019
\end{tabular}


Tabel 3 menunjukkan bahwa responden petani berumur produktif. Hal ini dilihat dari jumlah petani (responden) dengan usia 20-35 tahun sebanyak 4 (empat) orang (13\%), 36-50 tahun sebanyak 18 (delapan belas) orang (60\%), 51-65 tahun sebanyak 7 (tujuh) orang (24\%) dan interval lebih dari 66 tahun sebanyak 1 (satu) orang (3\%). Pada umumnya petani responden berumur 36-50 tahun atau 60 persen dari keseluruhan responden, kategori umur tersebut secara fisik tergolong masih kuat untuk bekerja mengelola usahatani bawang daun.

\section{Tingkat Pendidikan}

Pendidikan merupakan faktor yang sangat penting bagi peningkatan SDM. Adanya pendidikan yang memadai dapat meningkatkan kecakapan petani dalam mengusahakan usahataninya sehingga dapat menguntungkan dan meningkatkan taraf hidupnya. Pendidikan berpengaruh juga terhadap kemampuan berpikir dan beradaptasi dengan lingkungannya. Tingkat pendidikan responden dapat dilihat pada Tabel 4.

Tabel 4 Jumlah Petani Menurut Tingkat Pendidikan

\begin{tabular}{lcr}
\hline \multicolumn{1}{c}{ Pendidikan } & Jumlah petani (Orang) & Persentase (\%) \\
\hline SD & 7 & 23 \\
SMP & 11 & 37 \\
SMA & 11 & 37 \\
S-I & 1 & 3 \\
\hline Jumlah & 30 & 100 \\
\hline Sumber : Diolah dari data primer, 2019 &
\end{tabular}

Sumber : Diolah dari data primer, 2019

Tabel 4 menunjukkan bahwa pendidikan petani di Desa Sinsingon berjenjang dari sekolah dasar (SD) sampai strata 1 (S-I). Persentase terbesar adalah berpendidikan SMP dan SMA, yaitu pendidikan SMP sebanyak 11 petani atau $37 \%$ dan berpendidikan SMA sebanyak 11 petani atau $37 \%$. Berpendidikan SD sebanyak 7 petani atau $23 \%$, dan 1 petani atau $3 \%$ berpendidikan S-I.

\section{Jumlah Tanggungan Anggota Keluarga}

Tanggungan keluarga petani meliputi istri, anak-anak dan anggota keluarga lainnya yang bersama-sama dengan petani, jumlah tanggungan anggota keluarga dapat dilihat pada Tabel 5 .

\begin{tabular}{lcr}
\multicolumn{3}{c}{ Tabel 5. Jumlah Tanggungan Anggota Keluarga Petani } \\
\hline $\begin{array}{l}\text { Jumlah anggota } \\
\text { keluarga (orang) }\end{array}$ & Jumlah petani (orang) & Persentase (\%) \\
\hline 0 & & 3 \\
$1-2$ & 13 & 43 \\
$3-4$ & 16 & 54 \\
\hline Jumlah & 30 & 100 \\
\hline
\end{tabular}

Sumber : Diolah dari data primer, 2019
Tabel 5 menunjukkan bahwa sebagian besar petani mempunyai jumlah tanggungan $3-4$ orang, dengan persentase jumlah petani adalah $54 \%$ atau berjumlah 16 orang petani.

\section{Pengalaman Berusahatani Bawang Daun}

Pengalaman berusahatani merupakan salah satu faktor penentu keberhasilan usahatani. Petani yang sudah berpengalaman dalam usahatani cenderung lebih terampil dalam mengelola usaha taninya. Berdasarkan pengalaman tersebut, petani dapat meningkatkan produksi bawang daun melalui komunikasi antar petani. Pengalaman berusahatani bawang daun dapat dilihat pada Tabel 6.

\begin{tabular}{ccrr}
\multicolumn{6}{l}{ Tabel 6. Pengalaman Berusahatani Bawang Daun } \\
\hline \multirow{2}{*}{ No } & Pengalaman (Tahun) & \multicolumn{2}{c}{ Jumlah Responden (Orang) } \\
\cline { 3 - 4 } & & Jumlah & Persentase (\%) \\
\hline 1 & $2-10$ & 21 & 70 \\
2 & $11-20$ & 8 & 27 \\
3 & $21-25$ & 1 & 3 \\
\hline \multicolumn{2}{l}{ Jumlah } & 30 & 100 \\
\hline \multicolumn{3}{l}{ Sumber : Diolah dari data primer, 2019}
\end{tabular}

Tabel 6 menunjukkan bahwa pengalaman petani bekerja sebagai petani bawang daun 2 sampai 10 tahun sebanyak 21 responden dengan persentase $70 \%$, 11 sampai 20 tahun sebanyak 8 responden dengan persentase $27 \%$, dan 21 sampai 25 tahun sebanyak 1 responden dengan persentase $3 \%$. Tingkat pengalaman berusahatani bawang daun bagi sebagian besar petani sudah cukup berpengalaman sehingga dalam menjalankan aktifitasnya sebagai petani bawang daun cukup baik dan tanaman bawang daun sudah cukup produktif. Dalam halnya bertani, petani mengenal tanaman bawang daun sudah lama dan teknik budidaya bawang daun sudah turun temurun.

\begin{tabular}{lcr}
\multicolumn{3}{l}{ Tabel 7. Luas Lahan Petani } \\
\hline Luas Lahan (Ha) & Jumlah Petani (orang) & Persentase (\%) \\
\hline$<0,25$ & 22 & 74 \\
$0,26-0,50$ & 6 & 20 \\
$0,51-0,75$ & 1 & 3 \\
$0,76-1$ & 1 & 3 \\
\hline Jumlah & 30 & 100 \\
\hline
\end{tabular}

Sumber : Diolah dari data primer, 2019

Tabel 7 menunjukkan bahwa jumlah petani terbanyak dalam mengelolah lahan untuk usahatani bawang daun pada luas lahan $<0,25$ ha yaitu sebanyak 22 orang, atau sekitar $74 \%$. Sedangkan jumlah petani bawang daun paling sedikit yaitu pada luas lahan 0,51-0,75 ha dan luas lahan 0,76-1 ha masing-masing sebanyak 1 orang atau sekitar $3 \%$. 
Rata-rata penggunaan lahan pada usahatani bawang daun di Desa Sinsingon adalah 0,22 ha sedangkan untuk status kepemilikan lahan usahatani bawang daun adalah milik sendiri dari masing-masing petani.

\section{Status Kepemilikan Lahan}

Status kepemilikan lahan sangat berpengaruh terhadap tingkat pendapatan petani karena status kepemilikan lahan juga mempengaruhi biaya yang akan dikeluarkan oleh petani.

Kepemilikan lahan petani bawang daun di Desa Sinsingon adalah milik sendiri dengan persentase $100 \%$. Para pertani responden menggarap lahannya dengan membudidayakan berbagai macam jenis tanaman seperti bawang daun, kentang, bawang merah, wortel, tomat, labu kuning, dan sebagainya.

\section{Biaya Produksi Usahatani Bawang Daun}

Biaya produksi yaitu biaya yang dikeluarkan petani dalam satu kali proses produksi, meliputi biaya tetap dalam usahatani bawang daun yaitu pajak tanah serta penyusutan alat sedangkan biaya tidak tetap yaitu biaya bibit, pupuk, pestisida dan tenaga kerja.

\section{Biaya tetap}

Biaya tetap terdiri dari biaya pajak, dan biaya peralatan.

\section{Pajak}

Pajak yaitu biaya tanah yang di bayar per tahun. Dalam hal ini biaya produksi dihitung per satu musim tanam. Menurut hasil penelitian, biaya pajak ditanggung oleh pemilik lahan sendiri yaitu sebanyak 30 petani. Pajak merupakan salah satu unsur biaya yang perlu diperhitungkan petani.

\section{Peralatan}

Pengelolaan usahatani bawang daun, peralatan yang diperlukan yakni cangkul, sekop dan hand sprayer. Seluruh petani yang ada di Desa Sinsingon memiliki dan menggunakan tiga macam alat tersebut, setiap tenaga kerja yang disewa dalam usahatani bawang daun menggunakan alatnya masing-masing. Oleh sebab itu perhitungan biaya penyusutan hanya alat milik petani.

Biaya tetap yaitu biaya yang tidak berhubungan langsung dengan barang yang di produksi, yaitu pajak serta penyusutan peralatan. Penyusutan yang dihitung adalah berdasarkan alatalat milik sendiri. Biaya penyusutan alat dapat dilihat pada Tabel 8 .
Tabel 8. Rata-Rata Biaya Tetap Pajak Dan Penyusutan Peralatan Usahatani Bawang Daun.

\begin{tabular}{lrr}
\hline Biaya Tetap & Rata-rata Per Petani (Rp) & $\begin{array}{r}\text { Rata-rata Per } \\
\text { Hektar }(\mathrm{Rp})\end{array}$ \\
\hline Pajak & $6.433,33$ & $28.588,36$ \\
Cangkul & $16.972,22$ & $75.420,93$ \\
Sekop & $4.088,89$ & $18.170,15$ \\
Hand Sprayer & $44.805,56$ & $199.106,30$ \\
\hline Jumlah & $72.300,00$ & $321.285,74$ \\
\hline Sumber : Diolah dari data primer, 2019
\end{tabular}

Tabel 8 menunjukkan bahwa rata-rata biaya pajak dan penyusutan peralatan pada usahatani bawang daun di Desa Sinsingon adalah Rp.72.300,00-/petani dan Rp.321.285,74-/Ha. Biaya penyusutan diatas di peroleh dari pengurangan harga awal dan harga akhir dibagi dengan waktu pakai, sedangkan perhitungan pajak diperoleh dari pajak lahan pertahun dibagi dengan jangka waktu satu kali proses produksi.

\section{Biaya tidak tetap (Variabel)}

Biaya tidak tetap (variable) terdiri dari bibit, tenaga kerja, pengolahan lahan, penanaman, penyemprotan, penyiangan, pemupukan, penimbunan, pupuk, pestisida, panen.

\section{Bibit}

Bibit merupakan faktor produksi yang penting karena menjadi cikal bakal tanaman bawang daun. Rata-rata biaya bibit bawang daun yang ditanam oleh petani bawang daun di Desa Sinsingon Rp.35.979.855,00-/Ha.

\section{Tenaga Kerja}

Petani bawang daun di Desa Sinsingon menggunakan tenaga kerja pada tahap pengolahan lahan, penanaman, penyemprotan, penyiangan, pemupukan, dan penimbunan dengan waktu kerja 6 jam yaitu dari pukul 07.00 sampai dengan pukul 13.00. Upah tenaga kerja yang berlaku di Desa Sinsingon, Kecamatan Passi Timur terbagi dua jenis yaitu, untuk upah tenaga kerja pada pengolahan lahan Rp.100.000 dan untuk upah tenaga kerja pada penanaman sampai penimbunan Rp. 70.000 .

\section{Pengolahan Lahan}

Petani bawang daun di Desa Sinsingon melakukan pengolahan lahan atau bedengan sebelum penanaman. Upah tenaga kerja pada tahap ini Rp 100.000, biasanya tenaga kerja yang di pakai pada tahap pengolahan lahan sekitar \pm 35 orang per hektar. Total biaya pengolahan lahan sekitar Rp.3.510.591,02-/ha. 


\section{Penanaman}

Tahap penanaman ini dilakukan setelah pengolahan lahan. Upah tenaga kerja pada tahap ini Rp 70.000, biasanya tenaga kerja yang di pakai pada tahap penanaman sekitar \pm 31 orang per hektar. Total biaya penanaman sekitar Rp.2.233.743,14-/ha.

\section{Penyemprotan}

Penyemprotan merupakan salah satu faktor penting dalam menentukan produksi bawang daun, penyemprotan dilakukan pada saat tanaman bawang daun berumur 15-70 hari. Upah tenaga kerja pada tahap ini Rp 70.000, biasanya tenaga kerja yang di pakai pada tahap penyemprotan sekitar \pm 18 orang per hektar. Total biaya pengolahan lahan sekitar Rp.1.285.735,44-/ha.

\section{Penyiangan}

Perawatan tanaman bawang daun dilakukan penyiangan yaitu pembersihan rumput (gulma) yang menjadi pesaing utama tanaman bawang daun dalam memperoleh sinar matahari dan unsur unsur tanah. Gulma pada lahan pertama dapat berkompetisi dengan tanaman dalam hal penggunaan air, unsur hara, cahaya matahari dan ruang hidup. Oleh karena itu dilakukan penyiangan. Penyiangan dilakukan dengan cara manual yaitu dengan mencabut atau di gali dengan menggunakan alat khusus apabila rumput atau gulmanya telah tumbuh besar. Pada saat penyiangan, petani biasa mencabut dan membuang tanaman bawang daun yang terkena penyakit atau hama. Pada penanaman bawang daun penyiangan biasanya dilakukan 1-2 kali dalam satu kali panen. Upah tenaga kerja pada tahap ini $\mathrm{Rp}$ 70.000 , total biaya pengolahan lahan sekitar Rp.1.793.808,32-/ha.

\section{Pemupukan}

Pemupukan bawang daun dilakukan III tahap yaitu, tahap I dilakukan pada saat tanaman berumur 15 hari. Pemupukan ke II dilakukan 30 hari. Sedangkan Pemupukan ke III dilakukan 45 hari. Upah tenaga kerja pada tahap ini Rp 70.000, total biaya pemupukan sekitar Rp.622.130,05-/ha.

\section{Penimbunan}

Pada tahap penimbunan ini dilakukan saat tanaman bawang daun berumur 50-60 hari. Upah tenaga kerja pada tahap ini Rp 70.000, biasanya tenaga kerja yang di pakai pada tahap penimbunan sekitar \pm 18 orang per hektar. Total biaya pengolahan lahan sekitar Rp.1.267.960,30-/ha.

\section{Pupuk}

Pupuk adalah faktor penting dalam upaya peningkatan hasil produksi suatu usahatani. Dalam pertanian dikenal dua jenis pupuk yaitu pupuk organik dan non organik. Sebagian besar Usahatani bawang daun di Desa Sinsingon masih menggunakan jenis pupuk kimia/non organik. Perlu diketahui bahwa pada tahap I pupuk yang digunakan adalah pupuk organik yaitu pupuk petroganik . Pada tahap II dan III pupuk yang digunakan adalah pupuk kimia dengan campuran dari pupuk urea, ponska, SP dan mutiara disesuaikan dengan kebutuhan tanaman bawang daun. Pada tahap IV pupuk yang digunakan adalah pupuk daun yaitu campuran dari petrovita, gandasil B dan $\mathrm{D}$, bayfoland, ultradap, gibro disesuaikan dengan kebutuhan tanaman bawang daun. Rata-rata biaya penggunaan pupuk Rp.424.450,00-/petani dan Rp.1.886.165,00-/ha.

\section{Pestisida}

Suatu usahatani gangguan hama dan penyakit tumbuhan menjadi masalah yang sangat mempengaruhi penurunan produktivitas hasil panen, begitu pula yang dialami para petani bawang daun yang ada di Desa Sinsingon. Pestisida yang biasanya digunakan adalah manzete, amistartop, sidametrin, corona, laconic, extratin disesuaikan dengan serangan $\mathrm{H} / \mathrm{P}$ tersebut. Penyemprotan pestisida dilakukan untuk mencegah $\mathrm{H} / \mathrm{P}$ menyerang tanaman bawang daun, sedangkan waktu penyemprotan dilakukan pada saat pagi hari pukul 06.00-09.00 dan pada sore hari dilakukan pada pukul 15.00-18.00 dalam keadaan cuaca mendung. Dalam satu kali musim tanam penyemprotan pestisida biasanya dilakukan 4-7 kali. Rata-rata penggunaan pestisida Rp. 224.666,70-/petani dan Rp. 998.370,60/ha.

\section{Panen}

Panen biasanya dilakukan pada saat tanaman bawang daun sudah berumur 60-100 hari. Pada tahap ini tidak ada biaya yang di keluarkan oleh petani karena seluruh biaya pemanenan akan ditanggung oleh pedagang pengumpul. Proses jual beli bawang daun dilakukan langsung di kebun dengan adanya kesepakatan harga antara petani dan pedagang pengumpul. Proses jual beli dilakukan langsung di kebun milik petani karena meminimalisir resiko.

Bawang daun dijual petani pada pengumpul dengan satuan larik, Satu larik berkisar antara $1 \mathrm{Kg}$ sampai $1,5 \mathrm{Kg}$, dimana dalam satu larik terdiri dari 4 atau 5 rumpun bawang daun dengan jarak antar larik yaitu $25 \mathrm{~cm}$, dan jarak antar tanaman yaitu $15 \mathrm{~cm}$. 
Biaya tidak tetap (Variabel) pada usahatani bawang daun di Desa Sinsingon meliputi pengadaan bibit, pupuk, pestisida, dan biaya tenaga kerja dapat dilihat pada Tabel 9.

\begin{tabular}{lrr}
\multicolumn{3}{c}{ Tabel 9. Rata-rata Biaya Variabel Usahatani Bawang Daun } \\
\hline \multicolumn{1}{c}{ Biaya variabel } & $\begin{array}{r}\text { Rata-rata } \\
\text { Per Petani (Rp) }\end{array}$ & $\begin{array}{r}\text { Rata-rata Per } \\
\text { Hektar (Rp) }\end{array}$ \\
\hline Bibit & $8.096 .666,70$ & $35.979 .855,00$ \\
Pengolahan Lahan & $790.000,00$ & $3.510 .591,02$ \\
Penanaman & $502.666,67$ & $2.233 .743,14$ \\
Penyemprotan & $289.333,33$ & $1.285 .735,44$ \\
Penyiangan & $403.666,67$ & $1.793 .808,32$ \\
Pemupukan & $140.000,00$ & $622.130,05$ \\
Penimbunan & $342.400,00$ & $1.267 .960,30$ \\
Pupuk & $424.450,00$ & $1.886 .165,00$ \\
Pestisida & $224.666,70$ & $998.370,60$ \\
\hline Jumlah & $11.156 .783,00$ & $49.578 .359,00$ \\
\hline Sumber : Diolah dari data primer, 2019 &
\end{tabular}

Tabel 9 menunjukkan rata-rata biaya variabel usahatani bawang daun per petani adalah Rp. 11.156.783,00 sedangkan rata-rata per hektar adalah Rp. 49.578.359,00. Petani bawang daun selama satu kali proses produksi mengeluarkan biaya untuk bibit sebesar Rp.8.096.666,70- biaya tenaga kerja sebesar Rp.2.411.000,00 biaya pupuk sebesar Rp. 424.450,00- biaya pestisida sebesar Rp. 224.666,70-.

\section{Total Biaya Produksi}

Total biaya produksi adalah jumlah dari biaya tetap ditambah dengan jumlah biaya variabel, sedangkan dalam penelitian ini yaitu jumlah dari biaya pajak dan penyusutan ditambah dengan biaya pengadaan benih, tenaga kerja, dan pemeliharaan, total biaya produksi dapat dilihat pada Tabel 10.

\begin{tabular}{|c|c|c|c|}
\hline No. & Jenis Biaya & $\begin{array}{r}\text { Rata-rata } \\
\text { Per Petani } \\
(\mathrm{Rp})\end{array}$ & $\begin{array}{r}\text { Rata-rata Per } \\
\text { Hektar } \\
(\mathrm{Rp})\end{array}$ \\
\hline 1 & $\begin{array}{l}\text { Biaya tetap } \\
\text { - Pajak dan Penyusutan Alat }\end{array}$ & $72.300,00$ & $321.285,74$ \\
\hline 2 & $\begin{array}{l}\text { Biaya variabel } \\
\text { - Bibit } \\
\text { - Tenaga kerja } \\
\text { - Pupuk } \\
\text { - Pestisida }\end{array}$ & $\begin{array}{l}8.096 .666,70 \\
2.411 .000,00 \\
424.450,00 \\
224.666,70\end{array}$ & $\begin{array}{r}35.979 .855,00 \\
10.713 .968,00 \\
1.886 .165,00 \\
998.370,60\end{array}$ \\
\hline Jum & & $11.229 .083,30$ & $49.899 .644,50$ \\
\hline
\end{tabular}

Sumber : Diolah dari data primer, 2019

Rata-rata total biaya yang harus dikeluarkan oleh setiap petani dalam satu kali musim tanam adalah sebesar Rp.11.229.083,30 sedangkan rata-rata biaya produksi perhektar adalah Rp.49.899.644,50 untuk pengeluaran biaya terbanyak terdapat pada biaya bibit.

\section{Produksi}

Produksi yang dimaksud dalam penelitian ini antara lain jumlah produksi dan harga jual.

\section{Jumlah Produksi}

Produksi merupakan suatu kegiatan untuk meningkatkan manfaat dengan cara mengkombinasikan faktor-faktor produksi; tanah, tenaga kerja, modal dan manajemen.

Volume produksi merupakan faktor penentu besarnya pendapatan yang diterima oleh petani bawang daun itu sendiri. Semakin besar volume produksi yang dihasilkan, maka akan semakin tinggi pula pendapatan para petani bawang daun di Desa Sinsingon. Adapun volume produksi usahatani bawang dapat dilihat pada Tabel 11 .

\begin{tabular}{ccc}
\multicolumn{3}{c}{ Tabel 11. Volume Produksi Usahatani Bawang Daun } \\
\hline $\begin{array}{c}\text { Jumlah Produksi } \\
\text { (Larik) }\end{array}$ & $\begin{array}{c}\text { Jumlah Petani } \\
\text { (orang) }\end{array}$ & $\begin{array}{r}\text { Persentase } \\
(\%)\end{array}$ \\
\hline $1.000-9.000$ & 27 & 90 \\
$9.001-18.000$ & 2 & 7 \\
$18.001-27.000$ & 1 & 3 \\
\hline Jumlah & 30 & 100 \\
\hline Sumber : Diolah dari data primer, 2019 &
\end{tabular}

Tabel 11 menunjukkan bahwa banyaknya produksi bawang daun yang dihasilkan oleh petani bervariasi. Rata-rata produksi bawang daun yang dihasilkan oleh setiap petani di Desa Sinsingon adalah 6000 Larik sedangkan produksi bawang daun per hektar yaitu 26.662,72 Larik, dimana jumlah produksi tertinggi yakni 27.000 Larik didapati 1 orang petani atau $3 \%$. Sebagian besar petani bawang daun memproduksi 1.000-9000 Larik, yakni sebanyak 27 orang petani atau sekitar $90 \%$, sedangkan jumlah produksi diantara 9.00118.000 Larik sebanyak 2 orang atau hanya $7 \%$ dari jumlah responden.

\section{b. Harga Jual}

Harga merupakan persetujuan antara pembeli dan penjual dalam suatu produk tertentu, dalam hal ini petani merupakan penjual komoditi bawang daun. Harga jual adalah variabel paling utama dalam menentukan besarnya penerimaan suatu usahatani.

Harga yang berlaku pada tingkat petani bervariasi, harga tertinggi mencapai Rp. 5.000,/Larik dan harga terendah yaitu Rp. 3.500-/Larik, dengan demikian ditemukan rata-rata harga per petani yakni Rp. 4.066,67-/Larik. 


\section{Penerimaan Usahatani Bawang Daun}

Penerimaan usahatani bawang daun adalah perkalian antara jumlah produksi bawang daun dan harga jual ditingkat petani. Oleh karena itu besarnya penerimaan usahatani bawang daun tergantung pada jumlah produksi dan harga tersebut.

Hasil penelitian menunjukkan bahwa besarnya penerimaan usahatani bawang daun di Desa Sinsingon berkisar antara Rp.4.000.000,- sampai dengan Rp.108.000.000,- sedangkan rata-rata per petani Rp. 24.266.666,67- dan rata-rata per hektar adalah Rp. 107.835.876,20-.

\section{Pendapatan Usahatani Bawang Daun.}

Pendapatan merupakan hasil dari suatu usaha yang akan dinilai dari biaya yang dikeluarkan dan penerimaan yang diperoleh. Pendapatan usahatani bawang daun di Desa Sinsingon yaitu sebagai produk total usahatani dalam jumlah tertentu, baik yang dijual maupun yang tidak dijual. Pendapatan adalah selisi antara penerimaan dan semua biaya dengan rumus, yaitu:

$$
\begin{aligned}
\mathrm{TR} & =\mathrm{Y} . \mathrm{PY} \\
& =6000 \times 4.066,67 \\
& =24.400 .020 \\
\text { b) } \mathrm{TC} & =\mathrm{FC}+\mathrm{VC} \\
& =72.300+11.156 .783 \\
& =11.229 .083 \\
\text { c) } \mathrm{Pd} & =\mathrm{TR}-\mathrm{TC} \\
& =24.400 .020-11.229 .083 \\
& =13.170 .937
\end{aligned}
$$

Tabel 12. Pendapatan Usahatani Bawang Daun di Desa Sinsingon

\begin{tabular}{clrc}
\hline No & Uraian & $\begin{array}{r}\text { Rata-rata Per } \\
\text { Petani (Rp) }\end{array}$ & $\begin{array}{c}\text { Rata-rata Per } \\
\text { Hektar (Rp) }\end{array}$ \\
\hline 1 & Penerimaan & 24.400 .020 & $108.428 .483,54$ \\
2 & Biaya & 11.229 .083 & $49.899 .644,74$ \\
3 & Pendapatan & 13.170 .937 & $58.528 .838,80$ \\
\hline \multicolumn{4}{l}{ Sumber : Diolah dari data primer, 2019 }
\end{tabular}

Tabel 12 menunjukkan bahwa pendapatan yang diperoleh oleh Usahatani Bawang Daun Di Desa Sinsingon Kecamatan Passi Timur yaitu sebesar Rp.13.170.937-/Petani dalam 6000 larik dan Rp.58.528.838,80-/Hektar dalam 26.662,72 larik. Dari data tersebut, dijelaskan bahwa total penerimaan lebih besar dari pada total biaya yang dikeluarkan.

\section{Hasil Analisis Revenue Cost Ratio}

Tingkat keuntungan ekonomis dalam penelitian ini untuk usahatani bawang daun di Desa Sinsingon dapat diketahui dengan menggunakan Analisis Revenue Cost Ratio. Analisis R/C adalah perbandingan antara penerimaan dan biaya.

$$
\begin{aligned}
\mathrm{a} & =\mathrm{R} / \mathrm{C} \\
& =24.400 .020 / 11.229 .083 \\
& =2,17
\end{aligned}
$$

Nilai $\mathrm{R} / \mathrm{C}$ ratio $=2,17$ yang telah diperoleh tersebut mempunyai arti bahwa usahatani bawang daun di Desa Sinsingon, Kecamatan Passi Timur, Kabupaten Bolaang Mongondow dalam satu kali proses produksi terlihat menguntungkan.

\section{KESIMPULAN DAN SARAN}

\section{Kesimpulan}

Berdasarkan hasil penelitian, maka dapat disimpulkan bahwa usahatani bawang daun di Desa Sinsingon menguntungkan dilihat dari besarnya pendapatan per petani rata-rata adalah Rp.13.170.937 per musim tanam dan ratio atau penerimaan dan pengeluaran (R/C) yaitu 2,17 .

\section{Saran}

Berdasarkan kesimpulan maka dapat dikemukakan saran yaitu petani di Desa Sinsingon tetap mempertahankan usahatani bawang daun karena masih sangat menguntungkan.

\section{DAFTAR PUSTAKA}

Cahyono, B. 2005. Teknik Budidaya dan Usahatani Bawang Daun. Kanisius. Yogyakarta.

Dewi. E. 2015. AnalisaUsahatani dan Efisiensi Pemasaran Bawang Daun (Allium Porrum B) di Kecamatan Ngantru Kabupaten Tulungagung. (Studi Kasus di Desa Pinggirsari Kecamatan Ngantru Kabupaten Tulungagung). Jurnal Agribisnis Fakultas PertanianUnita Vol. II No. 13 April 2015.

Meltin. L. 2009. Budidaya Tanaman Bawang Daun (Allium Fistulosum L) di Kebun Benih Hortikultura (KBH) Tawangmangu. Universitas Sebelas Maret.

Nurmanaf, A.R., 2003. Karakteristik Rumah tangga Petani Berlahan Sempit: Struktur dan Stabilitas Pendapatan di Wilayah Berbasis Lahan Sawah Tadah Hujan (Kasus di Propinsi Jawa Tengah dan Jawa Timur). Jurnal SOCA Vol. 3 No. 2. : Halaman 181 $-187$.

Rahardi, Roni Palungkum, Asiani Budiarti, 2004. Agribisnis Tanaman Sayuran. Penebar Swadaya, Jakarta. 